\title{
Review
}

\section{Major biological obstacles for persistent cell-based regeneration of articular cartilage}

\author{
Andre F Steinert ${ }^{1}$, Steven C Ghivizzani², Axel Rethwilm ${ }^{3}$, Rocky S Tuan ${ }^{4}$, Christopher H Evans ${ }^{5}$ \\ and Ulrich Nöth ${ }^{1}$
}

\author{
${ }^{1}$ Orthopaedic Center for Musculoskeletal Research, König-Ludwig-Haus, Julius-Maximilians-University, Würzburg, Germany \\ 2Department of Orthopaedics and Rehabilitation, University of Florida, Gainesville, FL, USA \\ 3 Institut für Virologie und Immunbiologie, Julius-Maximilians-University, Würzburg, Germany \\ ${ }^{4}$ Cartilage Biology and Orthopaedics Branch, National Institute of Arthritis, and Musculoskeletal and Skin Diseases, National Institutes of Health, \\ Department of Health and Human Services, Bethesda, MD, USA \\ ${ }^{5}$ Center for Molecular Orthopaedics, Harvard Medical School, Boston, MA, USA
}

Corresponding author: Andre F Steinert, a-steinert.klh@mail.uni-wuerzburg.de

Published: 5 June 2007

This article is online at http://arthritis-research.com/content/9/3/213

(C) 2007 BioMed Central Ltd

Arthritis Research \& Therapy 2007, 9:213 (doi:10.1186/ar2195)

\begin{abstract}
Hyaline articular cartilage, the load-bearing tissue of the joint, has very limited repair and regeneration capacities. The lack of efficient treatment modalities for large chondral defects has motivated attempts to engineer cartilage constructs in vitro by combining cells, scaffold materials and environmental factors, including growth factors, signaling molecules, and physical influences. Despite promising experimental approaches, however, none of the current cartilage repair strategies has generated long lasting hyaline cartilage replacement tissue that meets the functional demands placed upon this tissue in vivo. The reasons for this are diverse and can ultimately result in matrix degradation, differentiation or integration insufficiencies, or loss of the transplanted cells and tissues. This article aims to systematically review the different causes that lead to these impairments, including the lack of appropriate differentiation factors, hypertrophy, senescence, apoptosis, necrosis, inflammation, and mechanical stress. The current conceptual basis of the major biological obstacles for persistent cell-based regeneration of articular cartilage is discussed, as well as future trends to overcome these limitations.
\end{abstract}

\section{Introduction}

\section{Structure and function of articular cartilage}

Articular cartilage is a highly specialized tissue that protects the bones of diarthrodial joints from forces associated with load bearing and impact, and allows nearly frictionless motion between the articulating surfaces $[1,2]$. The extracellular matrix $(E C M)$ of articular cartilage is distinct from that of other connective tissues, consisting of an intricate network containing predominantly fibrillar collagens and proteoglycans. The collagens, types II, IX and XI, form a fibrous framework that gives the tissue its shape, strength and tensile stiffness [3]. Collagen type $\mathrm{VI}$ is found pericellularly around chondrocytes [4], and collagen type $X$ is found in calcifying cartilage [5]. Although collagen type $I$ is the most prevalent collagen throughout the body, the primary constituent of the articular cartilage matrix is type II, comprising $80 \%$ to $90 \%$ of the collagen content [3]. The proteoglycans in articular cartilage in their most abundant form exist as large hydrophilic aggregates, which contain the fluid component and control its movement. The level of compaction of the proteoglycans within the collagen lattice will determine their level of hydration and, in turn, the stiffness of the articular cartilage. The synthesis, incorporation and degradation of ECM proteins are orchestrated by chondrocytes that populate the matrix at low density [3]. Because articular cartilage is avascular, nutrients for the chondrocytes are supplied from the capillaries of the synovium and must diffuse into the synovial fluid and then into the cartilage matrix. Coordinated synthesis and proteolytic breakdown of certain ECM components by chondrocytes enables certain components of the cartilage matrix to undergo turnover and maintenance [3]. Factors that impair chondrocyte function can disrupt the equilibrium of synthesis and catabolism in favor of cartilage degradation, which over time can lead to osteoarthritis (OA) [6,7].

\section{Capacity of articular cartilage for repair}

As a result of injury or disease, articular cartilage frequently incurs damage, but has very limited ability to regenerate. In chondral defects, where a lesion is contained within the articular cartilage, there is no involvement of the vasculature.

$\mathrm{ACT}=$ autologous chondrocyte transplantation; $\mathrm{BMP}=$ bone morphogenetic protein; $\mathrm{ECM}=$ extracellular matrix; FGF = fibroblast growth factor; IGF = insulin-like growth factor; IHH = indian hedgehog; IL = interleukin; IL-1Ra = IL-1 receptor antagonist; MMP = matrix metalloproteinase; MSC = mesenchymal stem cell; $\mathrm{NO}=$ nitric oxide; $\mathrm{OA}=$ osteoarthritis; PTHrP = parathyroid hormone related peptide; RA = rheumatoid arthritis; $\mathrm{SOX}=$ $\mathrm{SRY}$ (sex determining region $\mathrm{Y}$ )-box; TGF = transforming growth factor; TNF = tumor necrosis factor. 
Consequently, progenitor cells in blood and marrow cannot enter the damaged region to influence or contribute to the reparative process. Resident articular chondrocytes do not migrate to the lesion, and no production of a reparative matrix occurs. Thus, the defect is not filled or repaired and essentially remains permanently $[1,2]$.

Osteochondral cartilage defects have suffered damage to both the chondral layer and bone plate, causing the rupture of blood vessels and ingress into the bone marrow. In this case, a repair response is initiated and generally begins with a hematoma that forms when blood escapes the damaged vasculature or marrow and enters the lesion [1,2]. The fibrin network within the hematoma traps platelets that, in turn, release various bioactive factors, including platelet derived growth factor (PDGF) and transforming growth factor (TGF)- $\beta$, that stimulate vascular invasion and migration of undifferentiated mesenchymal progenitor cells into the fibrin clot $[1,8]$. Within several days of injury, the progenitor cells proliferate and may or may not differentiate into chondrocytic cells that synthesize cartilaginous matrix. The resulting repair tissue, however, is poorly organized and contains significant amounts of collagen type I. This fibrocartilage tissue is mechanically inferior and breaks down with time and loading, becoming fragmented or disintegrating altogether $[1,2,8]$.

\section{Present status of cartilage repair}

The specialized architecture and limited repair capacity of articular cartilage, coupled with the high physical demands placed upon this tissue, make it exceedingly difficult to treat cartilage injury medically. Currently, there exists no pharmacological agent that promotes the healing of articular cartilage lesions, whether chondral or osteochondral. Thus, physicians have attempted various surgical methods to restore articular surfaces, which fall into three broad classifications.

The first type of approach entails the use of mechanical penetration of the subchondral bone by abrasion arthroplasty, Pridie drilling, or microfracture to disrupt the vasculature and marrow. This results in a large clot that fills the defect and enables the natural repair response to form fibrocartilage repair tissue, which is subordinate to normal cartilage in terms of mechanical properties $[1,2,8,9]$. However, these procedures are cost effective and clinically useful, as patients often have reduced pain and improved joint function, and are, therefore, generally used as first-line treatment for focal cartilage defects [9-12].

The second approach involves attempts to regenerate hyaline cartilage repair tissue through transplantation of tissues such as periosteum, perichondrium or osteochondral grafts $[2,8,13,14]$. Although short term results have been positive for a number of patients, the long term clinical results are uncertain, with tissue availability for transplant, especially in large cartilage defects, being a major limitation $[1,2,8]$. Therefore, the autologous chondrocyte transplantation (ACT) procedure has been developed and used clinically since 1987, in combination with a periosteal cover, to treat chondral or osteochondral defects of the knee with good clinical results [12,15-17]. However, for the first generation of $A C T$, various adverse events have been reported, including graft failure, delamination, tissue hypertrophy and chondromalacia $[18,19]$. In order to overcome some of these impairments, modern modifications of this procedure involve embedding chondrocytes in a three-dimensional matrix before transplantation into cartilage defects [19-21]. To date, only a few clinical studies have been conducted comparing ACT with other repair procedures for large defects, and these have shown no major differences in the respective outcomes [22-26]. Despite these advances, with most surgical interventions resulting in improvement of clinical symptoms such as pain relief, none of the current treatment options have regenerated long-lasting hyaline cartilage tissue to replace damaged cartilage $[1,2,12,16]$.

Tissue engineering approaches that deliver a matrix seeded with chondrogenic cells (chondrocytes or progenitor cells) and chondrogenic factors have also been evaluated experimentally, with basically the same long term overall results in vivo thus far $[27,28]$. Despite good in vitro data with different approaches, the reasons for the failure of cellbased cartilage repair approaches to form hyaline repair tissue in vivo remain largely unclear to date [2,27-29]. Although proof of principle has been provided that implanted chondrocytes can contribute to structural cartilage repair, the origin of cells persisting at the repair site, whether these are the originally transplanted cells or migrated ones from the subchondral marrow or the adjacent synovium, has not been entirely clarified yet $[2,30,31]$. Emerging data are elucidating not only the fate but also the function of the transplanted cells at the repair site, for example, suggesting that transplanted mesenchymal cells not only function as repair cells but also as trophic mediators that stimulate the surrounding tissues toward repair [32].

Biological obstacles to hyaline neocartilage formation comprise differentiation insufficiencies, loss of transplanted cells or tissues, matrix destruction and integration failures (Figure 1), which all can occur due to various reasons. Insights into these mostly interrelated mechanisms might help us to systematically direct therapeutic approaches toward the formation of a more hyaline cartilage repair tissue.

\section{Differentiation cues}

\section{Cartilage development and chondrogenesis}

During development, the process of chondrogenesis gives rise to the formation of cartilage and bony skeletal tissues. Chondrogenesis is typically initiated at sites of skeletal element generation by localized proliferation of mesenchymal cells guided by multiple growth factors and morphogens such as Wnts, TGF- $\beta$ s and fibroblast growth factors (FGFs) $[33,34]$. Subsequent aggregation and condensation of these 
Figure 1

\section{Inflammation}

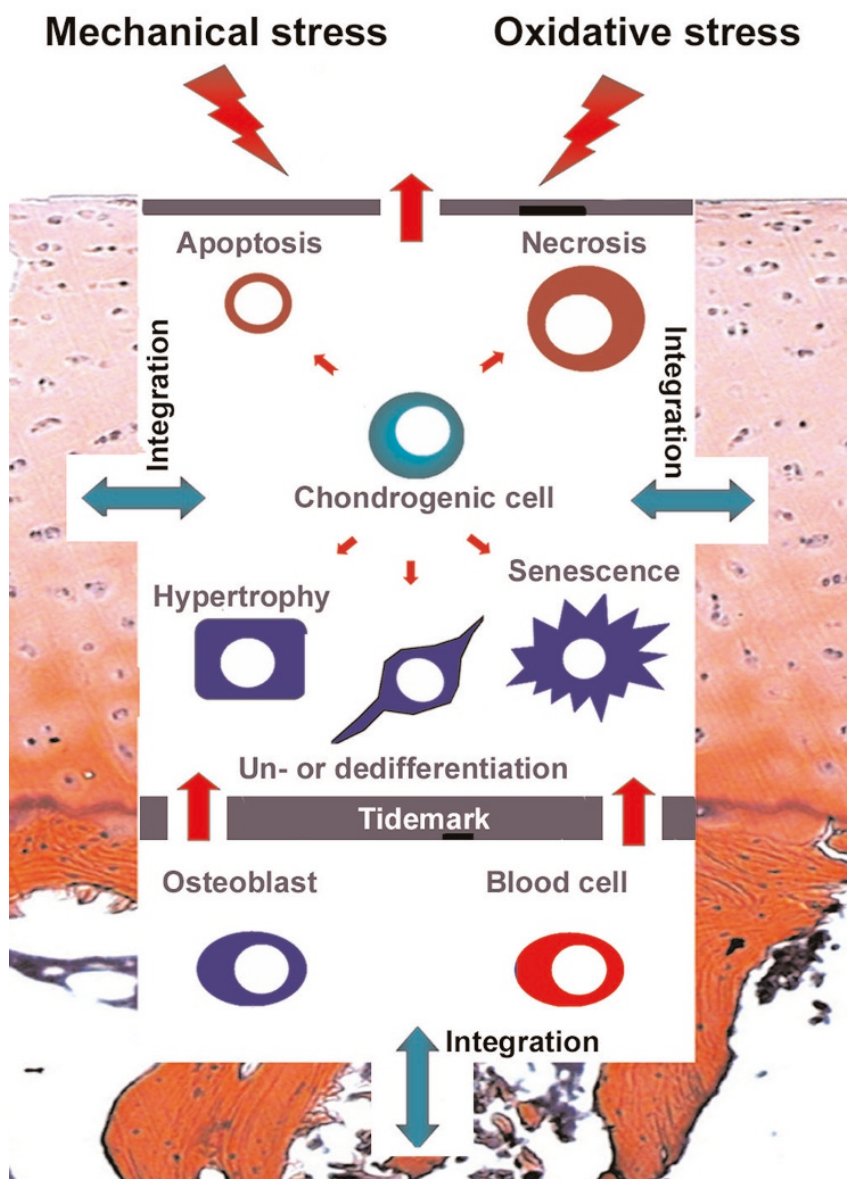

Biological obstacles associated with cell-based approaches to cartilage tissue engineering. Formation of hyaline neocartilage can be hindered due to loss of transplanted chondrogenic cells by cellular efflux, apoptosis or necrosis, differentiation insufficiencies, including fibroblastic, hypertrophic or osteogenic differentiation (red arrows), matrix destruction by mechanical, oxidative and/or inflammatory stressors (red flashes), as well as integration failures within the cartilage and/or bone compartment (green arrows) of the defect.

cells is mediated by both cell-cell (neural cadherin and neural cell adhesion molecule) and cell-matrix (hyaluronan and CD44, fibronectin, proteoglycans and collagens) adhesion, as well as numerous intracellular signaling pathways transduced by integrins, mitogen activated protein kinases, protein kinase $\mathrm{C}$, lipid metabolites and cyclic AMP and so on [35-40]. At this stage, the undifferentiated mesenchymal cells produce an ECM enriched with collagen type I, hyaluronan, tenascin and fibronectin. Mesenchymal cells in the precartilage aggregate and begin to synthesize and express molecules associated with chondrogenic differentiation, followed by their differentiation into chondroblasts and synthesis of extensive ECM containing proteoglycan and cartilage-specific collagen types II, IX, and XI [33,34].
Synthesis of collagen type I is reduced, as is expression of the cellular adhesion molecules. During development of the limbs and other bony tissues, chondrogenesis is gradually replaced by endochondral ossification. The chondrocytes within the cartilaginous tissue mature, hypertrophy and express collagen type $\mathrm{X}$ with reduced production of type II. The cartilage becomes vascularized and is infiltrated by osteoprogenitor cells. The chondrocytes undergo apoptosis, while the osteoprogenitor cells differentiate into osteoblasts and replace the cartilage with mineralized bone tissue $[33,34]$. During the developmental process a portion of the chondrocytes remains nonhypertrophic and expands to form the permanent cartilaginous tissues [33,34]. In the adult cartilage tissue, however, many of these developmental mechanisms are lost or only partially restored once the tissue is injured and repaired. Although adult cells, such as chondrocytes and mesenchymal stem cells, show fundamental biological differences compared to embryonic stem cells, including their limited potential to self-renew, they have been shown to be capable of greater plasticity than previously expected and to retain their potential to undergo chondrogenesis following considerable expansion in vitro [27,41-44]. A further understanding of the differentiation capacity of these cells, especially under aged and arthritic conditions, might be key to the successful application of adult chondrogenic cells in cartilage repair without evoking the ethical and legal issues associated with the use of embryonic stem cells $[28,41,45-47]$.

\section{Un- or dedifferentiated chondrogenic cells}

Still a matter of debate is whether to transplant a fully in vitro differentiated construct or a graft containing a homogeneous population of rather undifferentiated cells and signaling molecules, to ensure that the desired differentiation process takes place in vivo under physiological conditions of mechanical loading [2]. Each approach has its advantages and disadvantages. The former allows chondrogenic differentiation under controlled in vitro conditions, but is often associated with biocompatibility and integration problems $[48,49]$. The latter promotes integration well, but presents the risk of uncontrolled and undesired differentiation processes to occur $[48,50]$. Various cell types have been used to repair cartilage lesions, including chondrocytes, perichondrial or periosteal cells, and mesenchymal progenitor cells from bone marrow and other sources.

\section{Chondrocytes}

As mentioned above, only autologous chondrocytes are used in clinical practice. Human articular chondrocytes lose their chondrogenic phenotype upon monolayer expansion and change their morphology to a fibroblastic appearance [51]. However, dedifferentiated chondrocytes can re-differentiate toward the chondrogenic lineage in three-dimensional culture, particularly after conditioning by growth factors such as FGF-2, epidermal growth factor (EGF), TGF- $\beta$, or PDGF$B B$ during monolayer expansion [52-54]. The same is 
observed for constructs generated from OA chondrocytes, except with reduced rates of collagen production compared to constructs made from non-OA chondrocytes [55]. Next to age and underlying disease, a limited number of cell doublings is also important to sustain proper commitment in chondrocytes $[42,45]$, while extensive in vitro expansion of articular chondrocytes resulted in loss of in vivo cartilage formation [56].

Chondrocytes have been employed in conjunction with different matrix materials and growth factors in vitro and cartilage repair approaches in vivo (for reviews, see $[2,29,57,58])$. In each instance, improved repair was reported for the respective treatments, with the lesion being filled to a greater volume of tissue compared with untreated controls; however, the repair tissue generated was mainly fibrocartilaginous in nature. The transplanted chondrocytes or chondroblasts were concluded to have a beneficial effect on the spontaneous repair response, over and above that elicited by the matrix itself [2,27-29].

\section{Perichondrial/periosteal cells}

Cells derived from periosteum and perichondrium have been shown to have considerable chondrogenic potential [59]. These cells reside within the proliferative stratum of the cambial layer of the perichondrium and periosteum, respectively, and have been isolated for tissue engineering purposes [59]. The chondrogenic potential of perichondrial and periosteal cells for their use in cartilage repair has been tested extensively in vitro and in vivo following seeding into various matrices [2]. However, the need for two surgical interventions, the highly variable results achieved in experimental studies thus far, as well as the long-term instability of the repair tissue formed, may have prevented this approach from entering clinical practice to date.

\section{Mesenchymal stem cells}

Mesenchymal stem cells (MSCs) are multilineage progenitor cells responsible for the turnover and repair of mesenchymal tissues, such as bone, cartilage, ligament, muscle, and fat $[41,44,60,61]$. Although no clear definitive phenotype of MSCs has been described, through the use of the proper culture conditions, expanded MSCs can be stimulated to differentiate along specific pathways, such as chondrogenesis, adipogenesis, and osteogenesis [41,43,60,61]. With regard to cell-based cartilage repair approaches, MSCs provide an attractive alternative to chondrocytes. Unlike mature chondrocytes, which must be surgically harvested from a very limited supply of non-weight-bearing articular cartilage, MSCs are relatively easy to obtain from bone marrow, and will maintain their multilineage potential with passage, enabling considerable expansion in culture $[8,29,32,44,46,62,63]$. For the purposes of cartilage repair, extensive analyses of the appropriate microenvironment to stimulate MSCs toward chondrogenesis in vitro have been performed. MSCs are commonly isolated by adherence to cell culture plastic or density-gradient fractionation, and, therefore, represent a heterogeneous population of cells $[41,44,46]$. Positive selection for chondroprogenitor cells has been achieved by conditioning media with growth factors such as FGF-2 or TGF- $\beta$ during monolayer expansion [64]. Although no definitive MSC marker has been identified, selection protocols for the same immunophenotype within the MSC population might also be employed to improve chondrogenic phenotype stability, with STRO-1, CD73 and CD106 among the most promising candidates for positive selection and CD11b, CD45, CD34, CD31 and CD117 among those for negative selection $[44,46]$.

Key steps in using MSCs for articular cartilage repair include the development of effective methods to stimulate MSCs toward chondrogenesis, maintenance of an articular cartilage phenotype without ossification or fibrinogenesis, and a delivery system to localize the cells within a lesion without inhibiting chondrogenic differentiation or the integrity of the repair tissue [2,8,27-29,44]. Building from these results, transplantation of chondrogenic grafts or chondrogenesis in osteochondral defects in vivo have been attempted with varying levels of success [2,8,27-29,44,65,66]. Such systems have been crucial to the elucidation of cell signaling pathways during chondrogenesis and the contributions of specific factors to this process, which include growth and adhesion factors, as well as mechanical stimuli [2,27-29,44]. However, although short term success in generating hyalinelike cartilage repair tissue after weeks in vivo has been demonstrated, the long-term stability of the tissue formed has been questioned, which is not surprising given the inferior fibrocartilaginous nature of the retrieved tissue after longer time points $[2,27-29,44]$. For the treatment of bone defects, bone-marrow stromal cells within three-dimensional constructs have already been applied to humans [67]. The first clinical results of the transplantation of autologous bone marrow stromal cells for the repair of full-thickness articular cartilage defects have also been reported $[68,69]$. Three patients were treated with collagen gel MSC-constructs, which were covered with a periosteal flap, and fibrocartilaginous defect filling was found after one year, as well as a significantly improved patient outcome in the respective follow-ups after one, four and five years $[68,69]$.

\section{Chondrocyte hypertrophy and osteogenesis}

During development of the limbs and other bony tissues, chondrogenesis is gradually replaced by endochondral ossification as described above, with indian hedgehog $(\mathrm{IHH})$, parathyroid hormone related peptide (PTHrP) and $\mathrm{Wnt} / \beta$ catenin pathways among the main regulators of these processes $[33,34,70]$. These regulatory mechanisms can be partially recapitulated in vitro by using chondrocytes or chondroprogenitor cells under the appropriate high-density three-dimensional culture conditions [27,28,42,44]. Although it was shown that in vitro chondrogenesis without significant levels of end stage hypertrophy is possible by using normal 
articular chondrocytes [71,72], data from in vitro chondrogenesis using MSCs [72-81] or OA chondrocytes [47,82,83] together with members of the TGF- $\beta$ superfamily reveal a significant level of chondrocyte hypertrophy, indicated by high levels of collagen type $X$ expression. Although the use of collagen type $\mathrm{X}$ as a marker of chondrocyte hypertrophy in MSC-based systems has been questioned [84], it correlates well thus far with the existing in vivo data. For example, MSCs genetically modified to express bone morphogenetic protein (BMP)-2 show a significant level of tissue hypertrophy and osteophyte formation when transplanted orthotopically to osteochondral defects [85] or ectopically $[79,86]$ in small animal models. Correspondingly, TGF- $\beta 1$ has been shown to induce fibrosis in joints of nude rats when it was directly delivered by first generation adenovirus [87]. Furthermore, implantation of chondrocytes genetically modified to express BMP-7 has been shown to generate good hyaline cartilage repair tissue after 6 weeks in vivo, but only bad results have been reported after one year, with loss of $72 \%$ to $100 \%$ of the transplanted cells [88]. We argue that this might be attributed to mechanisms of hypertrophic differentiation and subsequent apoptosis, although experimental proof is not yet available.

Possible strategies to avoid hypertrophic differentiation of neocartilage constructs might be based on the use of cells that are not subjected to high doses of TGF- $\beta$ superfamily members, but are to their inhibitors, such as noggin, chordin $[89,90]$ or that are modified using small interfering RNAmediated knock down approaches, while chondrogenesis may be achieved via different pathways (for instance SOX9). Other potent molecules that might be considered for the facilitation of cartilage repair include $\mathrm{IHH}$, a member of the hedgehog family of cell surface-associated ligands. $\mathrm{IHH}$ is expressed in prehypertrophic chondrocytes of the growth plate and functions to inhibit chondrocyte hypertrophy by maintaining expression of $\mathrm{PTHrP}$ through a negative feedback loop [91,92]. Altering the expression of such proteins during chondrogenesis may serve to delay the onset of hypertrophy and formation of bone, while increasing the pool of proliferating chondrocytes. Indeed, addition of PTHrP has been shown to inhibit chondrocyte hypertrophy during in vitro chondrogenesis of primary, adult MSCs [81,91,93-100]. Hypertrophic differentiation of chondrocytes, as well as bone formation, is also regulated by the $\mathrm{Wnt} / \beta$-catenin pathway $[101,102]$. Specifically, recent developmental biology studies indicate that the transition from a nonhypertrophic to a hypertrophic chondrocyte appears to be under the control of the canonical Wnt signaling pathway (Wnt-5a) [34,70,102-104]. These molecules have also been shown to be involved in in vitro chondrogenesis of adult MSCs, making these molecules attractive targets for a possible therapeutic use $[101,102,105]$.

With regard to osteogenic infiltration from the underlying subchondral bone, adequate sealing structures in replace- ment of the tidemark (for example tissue sealants or semipermeable polymers) could be employed when treating osteochondral defects in order to avoid the entry of osteoblasts and red blood cells within the cartilage part of the lesion (Figure 1; see also 'Integration failures' below) $[2,20]$.

\section{Senescence}

Another mechanism limiting the function of transplanted cells for cartilage repair is aging or senescence. Articular chondrocytes and MSCs, like all human cells, can only undergo a finite number of replications in vitro, a phenomenon known as Hayflick's limit or replicative senescence [106-109]. Cellular senescence is associated with many molecular mechanisms, including telomere erosion and oxidative damage caused by $\mathrm{O}_{2}, \mathrm{H}_{2} \mathrm{O}_{2}$ and tert-butylhydroperoxide, leading to activation of $\mathrm{p53}$, retinoblastoma gene and insulin-like growth factor (IGF)/Akt pathways [106109]. In articular cartilage tissue, the number of chondrocytes decreases with increasing age, chondrocyte function deteriorates, and the ability of the cells to maintain or restore the tissue declines [110,111]. In parallel, senescent cells accumulate with age, and produce degradative enzymes and pro-inflammatory cytokines, which can disrupt the tissue structure and consecutively decrease tissue function [110,111]. The cells synthesize smaller aggrecans and less functional link protein, leading to the formation of smaller, more irregular proteoglycan aggregates [110,111]. Chondrocyte mitotic and synthetic activities decline with age, as well as age related responses to anabolic cytokines [110,112]. In parallel, chondrocyte and MSC telomere length declines and senescence-associated $\beta$-galactosidase expression increases with advancing age, suggesting that senescence contributes to the age-related deterioration of chondrocyte function, limiting their use for cartilage repair approaches $[45,109,112-114]$. Mediators that also promote premature stress-induced senescence of resident and transplanted cells include ethanol, ionizing radiations, mitomycin $\mathrm{C}$, or excessive mechanical stress, and have been associated with age-related pathologies such as $\mathrm{OA}$, which also involves pro-inflammatory cytokines such as IL-1 or tumor necrosis factor (TNF)- $\alpha$ [110,112,115,116]. Thus, senescent cells might contribute to aging and age-related pathology by stimulating tissue remodeling and/or local inflammation, which would compromise tissue structure and function. Telomerized cells have been used for tissue engineering applications [117], and other measures to inhibit replicative senescence have also been proposed [118]. It remains to be seen if such measures can be used to improve the outcome of cartilage repair approaches, especially when dealing with aged cells and patients [112].

\section{Delivery of chondrogenic factors and gene therapy}

With regard to cell-based therapies for articular cartilage regeneration, it is widely thought that exposure of chondrogenic cells (chondrocytes, periosteal/perichondrial cells, 
MSCs) to specific stimuli that promote chondrogenic differentiation and maintenance of the chondrocyte phenotype could significantly enhance the repair potential of this type of procedure and improve the clinical outcome. Potentially useful in this respect are members of the TGF- $\beta$ superfamily, including TGF- $\beta$ 1, 2, 3, and several BMPs, IGF-1, FGFs, and EGF, among others (reviewed in $[29,66]$ ). Another class of biologics that may be useful in cartilage differentiation repair are transcription factors that promote chondrogenesis or the maintenance of the chondrocyte phenotype. SRY (sex determining region $\mathrm{Y}$ )-box 9 (SOX9) and related transcription factors L-SOX5 and SOX6 have been identified as essential for chondrocyte differentiation and cartilage formation [99,100,119]. Signal transduction molecules, such as SMADs, which are mediators of TGF- $\beta$ and BMP signals, are also known to be important regulators of chondrogenesis $[120,121]$. However, the short half-lives of recombinant proteins and a lack of effective delivery methods for intracellular acting molecules hinder the clinical application of these factors.

Gene transfer offers an alternative approach to protein delivery that may satisfactorily overcome the limitations of conventional methods $[66,95,122,123]$. By delivering cDNAs that code for therapeutic proteins to specific target cells, the genetically modified cell is converted to a biofactory for protein production $[66,122,123]$. Through the localized delivery of gene transfer vectors or genetically modified cells to specific sites of cartilage damage, sustained protein synthesis can be concentrated at the site of injury or disease with minimal collateral exposure of non-target tissues [66]. Gene transfer approaches in vivo using various transgenes, including IGF-1, BMP-2, BMP-7, FGF-2, and SOX9, accelerated the healing of cartilage defects in various repair models [66,85,88,119,122-133]. Although short-term success in generating hyaline cartilage repair tissue after six weeks in vivo has been demonstrated, long-term in vivo analyses indicate only unsatisfactory results $[66,88,123]$. The possible causes are reviewed in this article. For a successful gene therapy approach for cartilage repair, the mode of delivery, level and duration of transgene expression, as well as the type and dosage of vectors used, have to be well considered [66,123]. For example, ubiquitous intra-articular expression of strong anabolic transgenes such as TGF- $\beta 1$ can cause severe fibrosis in joints [87], and excessive adenoviral loads are inhibitory to chondrogenesis of primary MSCs [134].

\section{Loss of transplanted cells or tissues}

As adult human articular cartilage is avascular and thought to be a post-mitotic tissue, with virtually no cell turnover and resident cells being encased within the dense extracellular matrix, there is no compensatory mechanism for loss of native and transplanted chondrogenic cells. In cartilage defects, cells can be lost due to leakage of cell suspension, apoptosis and necrosis.

\section{Delivery, surgical and biomaterial issues}

Surgical procedures such as tissue harvest for the ACT procedure or lesion-edge conditioning (performed to improve the fitting of an implant) inevitably affect healthy cartilage tissue surrounding the lesion site. These procedures are associated with an extensive margin of apoptosis and/or necrosis along the cut surfaces that is likely to create an unfavorable biological environment for graft integration, with scalpel margins being less affected than trephine wounds $[2,48]$. When periosteal flaps are used in first generation ACT procedures, significant problems were reported, including delamination, loss of flaps and cell suspension $[18,135]$.

Because of this and other reasons, chondrocytes have been incorporated in various matrix materials before transplantation in newer generations of ACT, including collagen and hyaluronic acid [19,136-138]. Various other scaffold materials have also been tested in vivo and in vitro for cartilage tissue engineering purposes (extensively reviewed elsewhere [2,19,20,27,29, 139-142]). From a biological perspective, beneficial material features would include not only a three-dimensional environment for differentiation and biocompatibility (no signs of cytotoxicity, apoptosis, senescence), but also would promote the release of factors supporting one or more biological aspects of repair, as outlined in other chapters of this review. Such so called third generation biomaterials have been manufactured for tissue engineering purposes [143-145]. For example, polylactic acid scaffolds have been engineered to release recombinant BMP-2 in a sustained fashion, which was sufficient to induce a favorable chondrogenic response in vitro [146]. However, the ideal material properties for a successful cartilage regeneration approach in vivo remain to be defined, including the biomechanical stability of the matrix, kinetics of resorption, selection of bioactive factor, cellular target(s) and mechanism of stimulation [142,146-148]. Given these imponderables, a guided biomaterial development focusing on cell and cartilage tissue specific requirements seems desirable.

\section{Apoptosis and necrosis}

As pointed out earlier, various stressors can affect neocartilage formation and integration, including pro-inflammatory cytokines such as IL-1 or TNF- $\alpha$, nitric oxide (NO), free radicals and oxidants, mechanical stress, glucocorticoids and others $[53,149]$. Depending on the cell type, as well as dose and type of stressor, the transplanted cells will react in different ways. For instance, a high, cytotoxic dosage of a stressor could cause a level of damage such that cellular biochemical activities decrease, leading to cellular death by necrosis. The level of damage sustained by cells determines whether programmed cell death (apoptosis) can unfold or, if the damage is lower, senescence can occur [150,151]. Since even after in vitro selection, transplanted cell populations are not homogeneous, the dose of the stressor will shift the percentage of cells executing each of the possible programs - cellular proliferation or inflammation, senescence (see above), apoptosis, and necrosis [152]. 
As outlined above, apoptosis naturally occurs during limb development following end stage terminal hypertrophic differentiation of chondrocytes, before osteoprogenitor cells infiltrate the cartilage anlagen and chondrogenesis is gradually replaced by endochondral ossification. Furthermore, it has been suggested that apoptosis of chondrocytes during development may act to control chondrocyte number in cartilage tissue, and current evidence indicates that chondrocyte apoptosis is involved in OA pathogenesis [153-155]. However, in cartilage repair, apoptotic cell death is obviously an undesired phenomenon, either when it occurs within the transplant or along with necrosis at the cut lesion edges of cartilage $[48,156]$. Apoptosis is characterized by specific hallmarks, such as loss of cellular membrane asymmetry, cell shrinkage, release of cytochrome c, chromatin condensation and degradation of nuclear DNA to 180 base-pair oligomeres, with caspases 3, 7, 9 and others mediating the apoptotic signaling program $[109,153,157,158]$. In vitro, chondrogenic cells respond to the same apoptosis-inducing signals as other cells, including FasL/CD95, TNF- $\alpha$, TRAIL (TNF-related apoptosis inducing ligand), IL-1, matrix metalloproteinase (MMP)-9, calcium and phosphate ions, NO, ceramide, retinoic acid, or serum deprivation and mechanical forces [150,154,159]. For example, TNF receptor mediated signaling simultaneously stimulates pathways for apoptosis induction via caspases and pathways for suppression of apoptosis via nuclear factor (NF)- $\mathrm{KB}$ $[109,150,154]$. Thus, the balance of these two signaling pathways determines the fate of cells after TNF- $\alpha$ stimulation. Interestingly, BMPs, specifically BMP-2, -4 and -7 , have been identified as key regulators inducing apoptosis during digit development, which was reversed by the BMP antagonist noggin [160]. Next to the avoidance of stressors named above, the use of apoptosis inhibitors that directly bind and inhibit caspases, such as $\mathrm{Bcl}-2$ or $\mathrm{Bcl}-\mathrm{XL}$, might be of therapeutic value in order to expand the lifespan of transplanted and resident cells [160-162]. Remarkably, it has also been shown that the dedifferentiation of chondrocytes, as well as the inhibition of apoptosis, is regulated by the Wnt/ $\beta$-catenin pathway $[34,163]$. Under arthritic conditions, Wnt-7a induces dedifferentiation of articular chondrocytes by stimulating transcriptional activity of $\beta$-catenin, whereas NOinduced apoptosis is inhibited via the activation of cell survival signaling, such as phosphatidylinositol 3-kinase and Akt, which block the apoptotic signaling cascade. Whether this mechanism can be harnessed therapeutically for the maintainance of chondrocyte populations, capable of building hyaline neocartilage, remains to be elucidated [163].

Besides induction of apoptosis, where cells can be eliminated without inflammation, cell death can be mediated by necrosis following a significant inflammatory response, due to the leakage of cell contents. Whereas the term 'necrosis' in the strict sense refers to changes secondary to cell death by any mechanism, including apoptosis, it is used here to describe a caspase-independent mode of cell death, as used previously by other groups [164-166]. Necrotic cell death is characterized by swelling of the cells and organelles, uncontrolled release of lysosomal enzymes and nuclear condensation (pycnosis) [164-166]. Thus, necrosis for cartilage repair is especially detrimental because of the associated inflammatory response, which interferes with chondrogenesis and the integrity of the cartilage matrix. The avoidance of cytotoxic stimuli during cartilage repair procedures, such as trephine wounds, needle stitches, and others (see above), is of ample importance for a successful repair, as well as anti-inflammatory measures where necrosis cannot be completely avoided.

Given the lack of cell supply in cartilage, major cell loss in cartilage and neo-cartilage will inevitably lead to tissue failure, as chondrogenic cells are the only source of matrix synthesis in theses tissues. Furthermore, recent studies are beginning to indicate a central role of the collagen framework in the maintenance of cartilage cells. However, whether cell loss is primary or secondary to cartilage matrix destruction is still a matter of debate $[154,167]$.

\section{Matrix degradation}

Damage to the cartilage ECM can arise focally after acute cartilage injury in an otherwise healthy joint, or from an underlying disease process, such as in OA or rheumatoid arthritis (RA).

\section{Mechanical factors}

As mentioned above, mechanical factors are integrally involved in cartilage matrix integrity, as well as survival and death of chondrogenic cells in native cartilage as well as repair tissues $[157,168,169]$. Quantitative analyses revealed that cartilage repair tissue after ACT has inferior mechanical properties compared to healthy cartilage in a large animal model [170,171]. In vitro studies using bovine cartilage explants showed that compressive stress, as low as $4.5 \mathrm{MPa}$, was able to induce apoptosis, while other parameters of matrix degradation, such as disruption of the collagen fibril network, tissue swelling, release of glycosaminoglycans, and increased nitrite levels, were apparent only at higher stress levels [172]. Beyond a threshold of $6 \mathrm{MPa}$, cell viability is inversely proportional to the applied stress [173]. In contrast, physical parameters have also been identified that aid the cartilage tissue quality in vitro [174-176] and in vivo after cell-based cartilage repair, comprising intermittent active or continuous active/passive motion and other techniques (reviewed in [2]). Therefore, post-operative care and physical therapy also play important roles in determining the healing outcome.

\section{Inflammation and degeneration}

Joint trauma, cartilage repair responses with or without different matrix materials, and diseases such as OA or RA can cause joint inflammation of varying intensities. The cytokines involved, including IL-1 and TNF- $\alpha$, have direct and indirect pro-inflammatory effects to regulate the degradation 
of ECM components by stimulating secretion of proteolytic enzymes and other mediators, such as MMPs, aggrecanases and other members of the 'a disintegrin and metalloproteinase with thrombospondin motifs' (ADAMTS) gene family, NO, and prostaglandin $E_{2}$ [149,177,178]. The importance of IL-1 is reinforced by the fact that it has been shown to inhibit chondrogenesis in chondrogenic cells in vitro by downregulation of chondrocyte differentiation state marker genes, such as those encoding SOX9, collagen type II and others, while upregulating $\mathrm{NO}$, prostaglandin $\mathrm{E}_{2}$ and MMP-3, and the finding that the effects could be inhibited by the addition of the $\mathrm{IL}-1$ receptor antagonist (IL-1Ra) [179-181]. However, much of this work was derived from research studying OA and RA [179,182-184]. Cell-based cartilage repair in OA knees has been attempted, with equal results compared to cartilage repair procedures in nonarthritic knees [50]. Inhibition of pro-inflammatory cytokines such as IL-1 may offer a useful supportive approach to the management of cartilage injury by reducing gene expression of genes involved in cartilage matrix degradation, and thus favoring a beneficial repair environment for transplanted chondrogenic cells [132,185-187]. The application of antiinflammatory cytokines is hindered by delivery problems. For example IL-1Ra is available as the drug 'Kineret' for the treatment of RA, and is self-administered at a daily dose of $100 \mathrm{mg}$ by subcutaneous injection, because it is neither feasible nor safe to deliver IL-1Ra by repeated intra-articular injection $[179,184]$. This treatment leads to a peak IL-1Ra serum concentration of approximately $1 \mu \mathrm{g} / \mathrm{ml}$, which is transient; the concentrations of IL-1Ra achieved in synovial fluid are unknown but they are likely to be low and also transient, explaining the limited success thus far using this drug in RA [179,184]. Gene delivery strategies to overcome these delivery issues have been devised [188-193], with a phase I clinical study having been completed for the treatment of RA [194,195] and an ongoing study for the treatment of OA [196]. Should these technologies prove to be safe and effective in the future, their use could be beneficially extended to the area of cartilage repair.

For treatment of local defects the use of growth factors, antiinflammatory cytokines or matrix molecules offers much promise as an approach to promote hyaline cartilage repair $[29,66,122,197]$. Since local defects are contained within healthy cartilage, it is likely that expression of certain growth factor and chondroprotective genes will be required for the length of time necessary to promote cartilage healing. The potential for gene therapy to promote cartilage repair in chronic diseases like RA and OA is more limited, due to more extensive cartilage loss, and altered metabolic responses of $\mathrm{OA}$ and RA chondrocytes.

\section{Integration failures}

One of the main biological challenges associated with cellbased cartilage repair procedures is integration of the graft tissue with the host. Depending on the nature of the cartilage injury, whether it is a chondral or osteochondral lesion, different aspects of transplant integration with cartilage and bone have to be appreciated.

With respect to integration of cartilage with cartilage, the nature and status of the tissue that comprises the wound lesion edge is central to tissue integration. As mentioned above, controlling aspects of cell differentiation, apoptotic or necrotic cell death together with matrix synthesis is the main factor influencing successful integration. Despite some cell migration potential from cartilage tissue in young experimental animals $[49,198]$, chondrocytes appear to have only a limited ability to infiltrate existing cartilage matrices and even to occupy empty chondrocyte lacunae [48]. However, integrative repair and chondrogenesis is not only a function of gross matrix synthesis, but is also affected by adjacent tissue structure and composition [199].

Another aspect is that blunt trauma to cartilage induces a greater proliferative response that extends to a greater distance from the lesion edge compared to burst and sharp trauma. However, in the case of sharp trauma, the basal cells enter proliferation before surface zone chondrocytes, which is not the case in blunt wounds [48]. Several measures have been used to promote this process by establishing good contact between cartilage transplants and native articular cartilage, including the use of collagen cross-linkers, brief enzymatic digestion and biological glues (tissue transglutaminase and other adhesives; reviewed in [2]).

With respect to the repair of osteochondral defects, two distinct types of tissues, articular cartilage and subchondral bone, are involved. In designing a multiphase implant, the healing of the underlying subchondral region of the defect site is critical as it supports the overlying neocartilage regeneration [49,200-202]. In order to protect the cartilage graft from stromal cell invasion from the underlying bone and dedifferentiation in osteochondral lesions, there have been attempts to mimic the tidemark with the use of biological sealants [20]. However, there have not been any controlled studies to date to validate this procedure. Initial studies have been performed to generate biphasic transplants in order to promote graft integration with the underlying bone in vitro, with a tidemark being already integrated [49,200-202]. Also, initial in vivo studies regenerating the subchondral layer by using MSCseeded poly- $\varepsilon$-caprolactone scaffolds have been performed with successful results [203]. Although the fabrication of neocartilage with an appropriate zonal organization has been attempted [204,205], exact reproduction of the different zones of native articular cartilage, including the tidemark and underlying bone, has not been achieved to date. A fruitful interplay between cells, morphogens and scaffold technology will be crucial for successful cartilage-like patterning of transplants for successful integration. Optimization and development of these approaches will determine whether constructs are applicable for partial- or full-thickness defects. 
Table 1

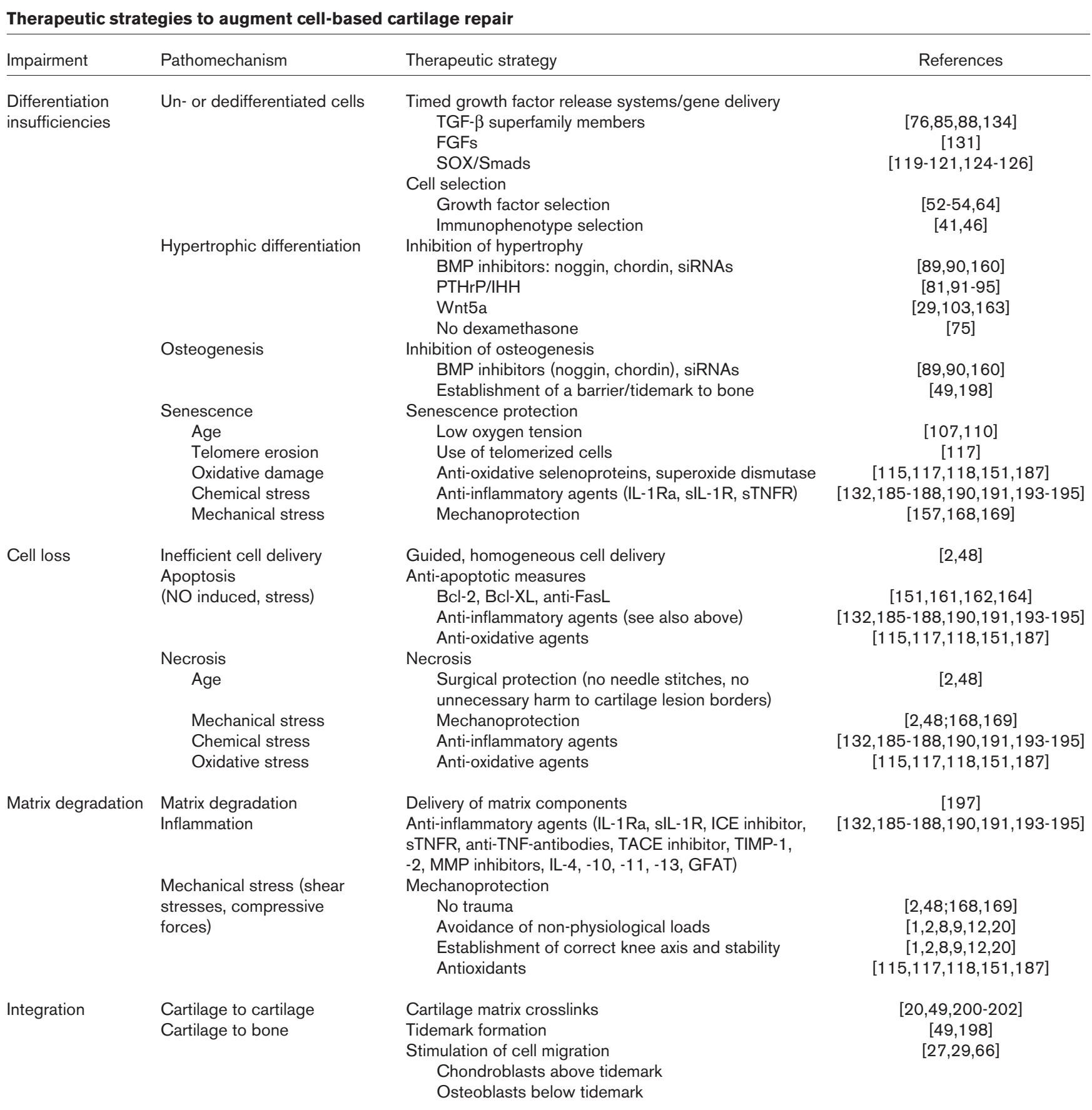

BMP, bone morphogenetic protein; FasL, Fas-Ligand; FGF, fibroblast growth factor; GFAT, fructose-6-phosphatase amido transferase; ICE, IL-1 converting enzyme; IHH, indian hedgehog; IL, interleukin; IL-1Ra, IL-1 receptor antagonist; MMP, matrix metalloproteinase; NO, nitric oxide; PTHrP, parathyroid hormone related peptide; slL-1R, soluble IL-1 receptor; siRNA, small interfering RNA; SOX, SRY (sex determining region Y)-box; sTNFR, soluble TNF receptor; TACE, TNF-alpha converting enzyme; TGF, transforming growth factor; TIMP, tissue inhibitor of matrix metalloproteinases; TNF, tumor necrosis factor.

\section{Conclusions and future perspectives}

Cell-based approaches to cartilage repair have only been introduced to the clinic by means of the ACT procedure, with good clinical results, but are still far from generating a repair tissue that is comparable to native cartilage in terms of tissue quality and stability. Although current treatments have limited effectiveness, an improved clinically useful repair approach does not necessarily have to demonstrate complete regeneration of normal tissue. The aim of this review is to critically analyze the current clinical and experimental 
cartilage repair approaches from a cell and molecular biological perspective in order to encourage the development of more rational approaches to repair. Considering the main biological obstacles to cartilage repair as outlined in this review (Figure 1), an ideal construct would contain hyaline differentiated tissue, and become fully integrated with the adjacent cartilage and bone, without the induction of an inflammatory response, senescence, apoptosis or necrosis. This aim may be overly optimistic to achieve in the near future, but the enabling technologies exist to address these issues. Efficient delivery of chondrogenic, anti-inflammatory and antioxidative factors seem to be of key importance (Table 1). As most of these factors are recombinant proteins, which have short half-lives, a repeated local administration is likely to be necessary to achieve the desired result, creating delivery problems. Gene transfer techniques could be adopted that might help us to overcome the limitations of the current treatments for damaged articular cartilage. Nonetheless, what remains to be determined are the exact factors needed for hyaline repair, including their bioactive level and duration of expression to meet the complexities of treating this tissue.

\section{Competing interests}

The authors declare that they have no competing interests.

\section{Acknowledgements}

This work is supported by grants from DFG (STE1051/2-1 to AFS and UN), IZKF (D-23/1 to AFS and AR), and NIH NIAMS (Intramural Research Program Z01 AR41131 to RST, and grants AR48566 and AR50249 to SCG and CHE). We apologize to investigators whose work could not be cited due to space limitations.

\section{References}

1. Buckwalter JA, Mankin $\mathrm{HJ}$ : Articular cartilage repair and transplantation. Arthritis Rheum 1998, 41:1331-1342.

2. Hunziker EB: Articular cartilage repair: basic science and clinical progress. A review of the current status and prospects. Osteoarthritis Cartilage 2002, 10:432-463.

3. Poole AR, Kojima T, Yasuda T, Mwale F, Kobayashi M, Laverty S: Composition and structure of articular cartilage: a template for tissue repair. Clin Orthop Relat Res 2001, 391(Suppl):S2633.

4. Poole CA, Glant TT, Schofield JR: Chondrons from articular cartilage. (IV). Immunolocalization of proteoglycan epitopes in isolated canine tibial chondrons. J Histochem Cytochem 1991, 39:1175-1187.

5. Kirsch T, von der Mark K: Isolation of human type $\mathbf{X}$ collagen and immunolocalization in fetal human cartilage. Eur $J$ Biochem 1991, 196:575-580.

6. Aigner T, Zien A, Gehrsitz A, Gebhard PM, McKenna L: Anabolic and catabolic gene expression pattern analysis in normal versus osteoarthritic cartilage using complementary DNAarray technology. Arthritis Rheum 2001, 44:2777-2789.

7. Fan Z, Bau B, Yang H, Soeder S, Aigner T: Freshly isolated osteoarthritic chondrocytes are catabolically more active than normal chondrocytes, but less responsive to catabolic stimulation with interleukin-1beta. Arthritis Rheum 2005, 52:136143.

8. Caplan Al, Elyaderani M, Mochizuki Y, Wakitani S, Goldberg VM: Principles of cartilage repair and regeneration. Clin Orthop 1997, 342:254-269.

9. Minas $\mathrm{T}$ : The role of cartilage repair techniques, including chondrocyte transplantation, in focal chondral knee damage. Instr Course Lect 1999, 48:629-643.

10. Steadman JR, Rodkey WG, Rodrigo JJ: Microfracture: surgical technique and rehabilitation to treat chondral defects. Clin Orthop Relat Res 2001, 391(Suppl):S362-369.
11. Steadman JR, Rodkey WG, Briggs KK: Microfracture to treat full-thickness chondral defects: surgical technique, rehabilitation, and outcomes. J Knee Surg 2002, 15:170-176.

12. Minas T, Nehrer S: Current concepts in the treatment of articular cartilage defects. Orthopedics 1997, 20:525-538.

13. Hangody L, Fules P: Autologous osteochondral mosaicplasty for the treatment of full-thickness defects of weight-bearing joints: ten years of experimental and clinical experience. $J$ Bone Joint Surg Am 2003, 85-A(Suppl 2):25-32.

14. Bouwmeester SJ, Beckers JM, Kuijer R, van der Linden AJ, Bulstra SK: Long-term results of rib perichondrial grafts for repair of cartilage defects in the human knee. Int Orthop 1997, 21:313317.

15. Brittberg $M$, Lindahl $A$, Nilsson $A$, Ohlsson $C$, Isaksson $O$, Peterson L: Treatment of deep cartilage defects in the knee with autologous chondrocyte transplantation. N Engl J Med 1994, 331:889-895.

16. Peterson L, Brittberg M, Kiviranta I, Akerlund EL, Lindahl A: Autologous chondrocyte transplantation. Biomechanics and longterm durability. Am J Sports Med 2002, 30:2-12.

17. Peterson L, Minas T, Brittberg M, Lindahl A: Treatment of osteochondritis dissecans of the knee with autologous chondrocyte transplantation: results at two to ten years. $J$ Bone Joint Surg Am 2003, 85-A(Suppl 2):1 7-24.

18. Wood JJ, Malek MA, Frassica FJ, Polder JA, Mohan AK, Bloom ET, Braun MM, Cote TR: Autologous cultured chondrocytes: adverse events reported to the United States Food and Drug Administration. J Bone Joint Surg Am 2006, 88:503-507.

19. Marlovits S, Zeller P, Singer P, Resinger C, Vecsei V: Cartilage repair: generations of autologous chondrocyte transplantation. Eur J Radio/ 2006, 57:24-31.

20. Behrens P, Bosch U, Bruns J, Erggelet C, Esenwein SA, Gaissmaier C, Krackhardt T, Lohnert J, Marlovits S, Meenen NM, et al.: [Indications and implementation of recommendations of the working group "Tissue Regeneration and Tissue Substitutes" for autologous chondrocyte transplantation (ACT)]. Z Orthop Ihre Grenzgeb 2004, 142:529-539.

21. Minas T, Peterson L: Advanced techniques in autologous chondrocyte transplantation. Clin Sports Med 1999, 18:13-44, v-vi.

22. Bartlett W, Skinner JA, Gooding CR, Carrington RW, Flanagan AM, Briggs TW, Bentley G: Autologous chondrocyte implantation versus matrix-induced autologous chondrocyte implantation for osteochondral defects of the knee: a prospective, randomised study. J Bone Joint Surg Br 2005, 87:640-645.

23. Bentley G, Biant LC, Carrington RW, Akmal M, Goldberg A, Williams AM, Skinner JA, Pringle J: A prospective, randomised comparison of autologous chondrocyte implantation versus mosaicplasty for osteochondral defects in the knee. J Bone Joint Surg Br 2003, 85:223-230.

24. Knutsen G, Engebretsen L, Ludvigsen TC, Drogset JO, Grontvedt T, Solheim E, Strand T, Roberts S, Isaksen V, Johansen O: Autologous chondrocyte implantation compared with microfracture in the knee. A randomized trial. J Bone Joint Surg Am 2004, 86-A:455-464.

25. Dozin B, Malpeli M, Cancedda R, Bruzzi P, Calcagno S, Molfetta L, Priano F, Kon E, Marcacci M: Comparative evaluation of autologous chondrocyte implantation and mosaicplasty: a multicentered randomized clinical trial. Clin J Sport Med 2005, 15:220-226

26. Henderson IJ, Tuy B, Connell D, Oakes B, Hettwer WH: Prospective clinical study of autologous chondrocyte implantation and correlation with MRI at three and 12 months. J Bone Joint Surg Br 2003, 85:1060-1066.

27. Kuo CK, Li WJ, Mauck RL, Tuan RS: Cartilage tissue engineering: its potential and uses. Curr Opin Rheumatol 2006, 18:6473.

28. Nesic D, Whiteside R, Brittberg M, Wendt D, Martin I, MainilVarlet $P$ : Cartilage tissue engineering for degenerative joint disease. Adv Drug Deliv Rev 2006, 58:300-322.

29. Tuli R, Li WJ, Tuan RS: Current state of cartilage tissue engineering. Arthritis Res Ther 2003, 5:235-238.

30. Shapiro F, Koide S, Glimcher MJ: Cell origin and differentiation in the repair of full-thickness defects of articular cartilage. $J$ Bone Joint Surg Am 1993, 75:532-553.

31. Dell'Accio F, Vanlauwe J, Bellemans J, Neys J, De Bari C, Luyten FP: Expanded phenotypically stable chondrocytes persist in the repair tissue and contribute to cartilage matrix formation 
and structural integration in a goat model of autologous chondrocyte implantation. J Orthop Res 2003, 21:123-131.

32. Caplan Al, Dennis JE: Mesenchymal stem cells as trophic mediators. J Cell Biochem 2006, 98:1076-1084.

33. Goldring MB, Tsuchimochi K, ljiri K: The control of chondrogenesis. J Cell Biochem 2006, 97:33-44.

34. Karsenty G, Wagner EF: Reaching a genetic and molecular understanding of skeletal development. Dev Cell 2002, 2:389406.

35. Frenz DA, Akiyama SK, Paulsen DF, Newman SA: Latex beads as probes of cell surface-extracellular matrix interactions during chondrogenesis: evidence for a role for amino-terminal heparin-binding domain of fibronectin. Dev Biol 1989, 136:8796.

36. Fukumoto T, Sanyal A, Fitzsimmons JS, O'Driscoll SW: Expression of beta1 integrins during periosteal chondrogenesis. Osteoarthritis Cartilage 2002, 10:135-144.

37. Knudson CB: Hyaluronan and CD44: strategic players for cellmatrix interactions during chondrogenesis and matrix assembly. Birth Defects Res C Embryo Today 2003, 69:174-196.

38. Tacchetti C, Tavella S, Dozin B, Quarto R, Robino G, Cancedda R: Cell condensation in chondrogenic differentiation. Exp Cell Res 1992, 200:26-33.

39. Tavella S, Bellese G, Castagnola P, Martin I, Piccini D, Doliana R, Colombatti A, Cancedda R, Tacchetti C: Regulated expression of fibronectin, laminin and related integrin receptors during the early chondrocyte differentiation. J Cell Sci 1997, 110: 2261-2270.

40. DeLise AM, Fischer L, Tuan RS: Cellular interactions and signaling in cartilage development. Osteoarthritis Cartilage 2000, 8:309-334.

41. Tuan RS, Boland G, Tuli R: Adult mesenchymal stem cells and cell-based tissue engineering. Arthritis Res Ther 2003, 5:32-45.

42. Giannoni P, Cancedda R: Articular chondrocyte culturing for cell-based cartilage repair: needs and perspectives. Cells Tissues Organs 2006, 184:1-15.

43. Jiang $\mathrm{Y}$, Jahagirdar $B N$, Reinhardt $R L$, Schwartz RE, Keene $C D$, Ortiz-Gonzalez XR, Reyes M, Lenvik T, Lund T, Blackstad M, et al.: Pluripotency of mesenchymal stem cells derived from adult marrow. Nature 2002, 418:41-49.

44. Chen FH, Rousche KT, Tuan RS: Technology Insight: adult stem cells in cartilage regeneration and tissue engineering. Nat Clin Pract Rheumatol 2006, 2:373-382.

45. Giannoni P, Pagano A, Maggi E, Arbico R, Randazzo N, Grandizio $\mathrm{M}$, Cancedda R, Dozin B: Autologous chondrocyte implantation (ACl) for aged patients: development of the proper cell expansion conditions for possible therapeutic applications. Osteoarthritis Cartilage 2005, 13:589-600.

46. Kolf CM, Cho E, Tuan RS: Mesenchymal stromal cells. Biology of adult mesenchymal stem cells: regulation of niche, selfrenewal and differentiation. Arthritis Res Ther 2007, 9:204.

47. Tallheden T, Bengtsson C, Brantsing C, Sjogren-Jansson E, Carlsson L, Peterson L, Brittberg M, Lindahl A: Proliferation and differentiation potential of chondrocytes from osteoarthritic patients. Arthritis Res Ther 2005, 7:R560-568.

48. Archer CW, Redman S, Khan I, Bishop J, Richardson K: Enhancing tissue integration in cartilage repair procedures. $J$ Anat 2006, 209:481-493.

49. Tognana E, Chen F, Padera RF, Leddy HA, Christensen SE, Guilak F, Vunjak-Novakovic G, Freed LE: Adjacent tissues (cartilage, bone) affect the functional integration of engineered calf cartilage in vitro. Osteoarthritis Cartilage 2005, 13:129-138.

50. Hollander AP, Dickinson SC, Sims TJ, Brun P, Cortivo R, Kon E, Marcacci M, Zanasi S, Borrione A, De Luca C, et al:: Maturation of tissue engineered cartilage implanted in injured and osteoarthritic human knees. Tissue Eng 2006, 12:1787-1798.

51. von der Mark K, Gauss V, von der Mark H, Muller P: Relationship between cell shape and type of collagen synthesised as chondrocytes lose their cartilage phenotype in culture. Nature 1977, 267:531-532.

52. Jakob M, Demarteau O, Schafer D, Hintermann B, Dick W, Heberer M, Martin I: Specific growth factors during the expansion and redifferentiation of adult human articular chondrocytes enhance chondrogenesis and cartilaginous tissue formation in vitro. J Cell Biochem 2001, 81:368-377.

53. Barbero A, Grogan S, Schafer D, Heberer M, Mainil-Varlet P, Martin I: Age related changes in human articular chondrocyte yield, proliferation and post-expansion chondrogenic capacity. Osteoarthritis Cartilage 2004, 12:476-484.

54. Barbero A, Ploegert S, Heberer M, Martin I: Plasticity of clonal populations of dedifferentiated adult human articular chondrocytes. Arthritis Rheum 2003, 48:1315-1325.

55. Tallheden T, Dennis JE, Lennon DP, Sjogren-Jansson E, Caplan Al, Lindahl A: Phenotypic plasticity of human articular chondrocytes. J Bone Joint Surg Am 2003, 85-A(Suppl 2):93-100.

56. Dell'Accio F, De Bari C, Luyten FP: Molecular markers predictive of the capacity of expanded human articular chondrocytes to form stable cartilage in vivo. Arthritis Rheum 2001, 44: 1608-1619.

57. Raghunath J, Rollo J, Sales KM, Butler PE, Seifalian AM: Biomaterials and scaffold design: key to tissue-engineering cartilage. Biotechnol App/ Biochem 2007, 46:73-84.

58. Lin Z, Willers $\mathrm{C}, \mathrm{Xu}$ J, Zheng MH: The chondrocyte: biology and clinical application. Tissue Eng 2006, 12:1971-1984.

59. O'Driscoll SW: Articular cartilage regeneration using periosteum. Clin Orthop 1999, 367(Suppl):S186-203.

60. Pittenger MF, Mackay AM, Beck SC, Jaiswal RK, Douglas R, Mosca JD, Moorman MA, Simonetti DW, Craig S, Marshak DR: Multilineage potential of adult human mesenchymal stem cells. Science 1999, 284:143-147.

61. Caplan AI, Bruder SP: Mesenchymal stem cells: building blocks for molecular medicine in the 21st century. Trends $\mathrm{Mol}$ Med 2001, 7:259-264.

62. Noth U, Tuli R, Osyczka AM, Danielson KG, Tuan RS: In vitro engineered cartilage constructs produced by press-coating biodegradable polymer with human mesenchymal stem cells. Tissue Eng 2002, 8:131-144.

63. Noth U, Osyczka AM, Tuli R, Hickok NJ, Danielson KG, Tuan RS: Multilineage mesenchymal differentiation potential of human trabecular bone-derived cells. J Orthop Res 2002, 20:10601069.

64. Im Gl, Jung NH, Tae SK: Chondrogenic differentiation of mesenchymal stem cells isolated from patients in late adulthood: the optimal conditions of growth factors. Tissue Eng 2006, 12 527-536.

65. Wakitani S, Goto T, Pineda SJ, Young RG, Mansour JM, Caplan Al, Goldberg VM: Mesenchymal cell-based repair of large, fullthickness defects of articular cartilage. J Bone Joint Surg Am 1994, 76:579-592.

66. Trippel SB, Ghivizzani SC, Nixon AJ: Gene-based approaches for the repair of articular cartilage. Gene Ther 2004, 11:351359.

67. Quarto R, Mastrogiacomo M, Cancedda R, Kutepov SM, Mukhachev V, Lavroukov A, Kon E, Marcacci M: Repair of large bone defects with the use of autologous bone marrow stromal cells. N Engl J Med 2001, 344:385-386

68. Wakitani S, Mitsuoka T, Nakamura N, Toritsuka Y, Nakamura Y, Horibe S: Autologous bone marrow stromal cell transplantation for repair of full-thickness articular cartilage defects in human patellae: two case reports. Cell Transplant 2004, 13: 595-600.

69. Kuroda R, Ishida K, Matsumoto T, Akisue T, Fujioka H, Mizuno K, Ohgushi H, Wakitani S, Kurosaka M: Treatment of a full-thickness articular cartilage defect in the femoral condyle of an athlete with autologous bone-marrow stromal cells. Osteoarthritis Cartilage 2007, 15:226-231.

70. Hartmann C, Tabin CJ: Dual roles of Wnt signaling during chondrogenesis in the chicken limb. Development 2000, 127:31413159 .

71. Binette F, McQuaid DP, Haudenschild DR, Yaeger PC, McPherson JM, Tubo R: Expression of a stable articular cartilage phenotype without evidence of hypertrophy by adult human articular chondrocytes in vitro. J Orthop Res 1998, 16:207-216.

72. Karlsson C, Brantsing C, Svensson T, Brisby H, Asp J, Tallheden $T$, Lindahl A: Differentiation of human mesenchymal stem cells and articular chondrocytes: analysis of chondrogenic potential and expression pattern of differentiation-related transcription factors. J Orthop Res 2007, 25:152-163.

73. Barry F, Boynton RE, Liu B, Murphy JM: Chondrogenic differentiation of mesenchymal stem cells from bone marrow: differentiation-dependent gene expression of matrix components. Exp Cell Res 2001, 268:189-200.

74. Hanada K, Solchaga LA, Caplan AI, Hering TM, Goldberg VM, Yoo JU, Johnstone B: BMP-2 induction and TGF-beta 1 modu- 
lation of rat periosteal cell chondrogenesis. J Cell Biochem 2001, 81:284-294.

75. Johnstone B, Hering TM, Caplan Al, Goldberg VM, Yoo JU: In vitro chondrogenesis of bone marrow-derived mesenchymal progenitor cells. Exp Cell Res 1998, 238:265-272.

76. Steinert A, Weber M, Dimmler A, Julius C, Schutze N, Noth U, Cramer H, Eulert J, Zimmermann U, Hendrich C: Chondrogenic differentiation of mesenchymal progenitor cells encapsulated in ultrahigh-viscosity alginate. J Orthop Res 2003, 21:10901097.

77. Yoo JU, Barthel TS, Nishimura K, Solchaga L, Caplan Al, Goldberg VM, Johnstone B: The chondrogenic potential of human bone-marrow-derived mesenchymal progenitor cells. J Bone Joint Surg Am 1998, 80:1745-1757.

78. Winter A, Breit S, Parsch D, Benz K, Steck E, Hauner H, Weber $\mathrm{RM}$, Ewerbeck V, Richter W: Cartilage-like gene expression in differentiated human stem cell spheroids: a comparison of bone marrow-derived and adipose tissue-derived stromal cells. Arthritis Rheum 2003, 48:418-429.

79. Pelttari K, Winter A, Steck E, Goetzke K, Hennig T, Ochs BG, Aigner T, Richter W: Premature induction of hypertrophy during in vitro chondrogenesis of human mesenchymal stem cells correlates with calcification and vascular invasion after ectopic transplantation in SCID mice. Arthritis Rheum 2006, 54:3254-3266

80. Sekiya I, Colter DC, Prockop DJ: BMP-6 enhances chondrogenesis in a subpopulation of human marrow stromal cells. Biochem Biophys Res Commun 2001, 284:411-418.

81. Kafienah W, Mistry S, Dickinson SC, Sims TJ, Learmonth I, Hollander AP: Three-dimensional cartilage tissue engineering using adult stem cells from osteoarthritis patients. Arthritis Rheum 2007, 56:177-187.

82. Yang $K G$, Saris $D B$, Geuze RE, van Rijen $M H$, van der Helm $Y J$, Verbout AJ, Creemers LB, Dhert WJ: Altered in vitro chondrogenic properties of chondrocytes harvested from unaffected cartilage in osteoarthritic joints. Osteoarthritis Cartilage 2006, 14:561-570.

83. Aigner $\mathrm{T}$, Reichenberger $\mathrm{E}$, Bertling $\mathrm{W}$, Kirsch $\mathrm{T}$, Stoss $\mathrm{H}$, von der Mark K: Type $X$ collagen expression in osteoarthritic and rheumatoid articular cartilage. Virchows Arch B Cell Pathol Incl Mol Pathol 1993, 63:205-211.

84. Mwale F, Stachura D, Roughley P, Antoniou J: Limitations of using aggrecan and type $\mathrm{X}$ collagen as markers of chondrogenesis in mesenchymal stem cell differentiation. $J$ Orthop Res 2006, 24:1791-1798.

85. Gelse K, von der Mark K, Aigner T, Park J, Schneider H: Articular cartilage repair by gene therapy using growth factor-producing mesenchymal cells. Arthritis Rheum 2003, 48:430-441.

86. De Bari C, Dell'Accio F, Luyten FP: Failure of in vitro-differentiated mesenchymal stem cells from the synovial membrane to form ectopic stable cartilage in vivo. Arthritis Rheum 2004, 50:142-150.

87. Mi Z, Ghivizzani SC, Lechman E, Glorioso JC, Evans $\mathrm{CH}$, Robbins PD: Adverse effects of adenovirus-mediated gene transfer of human transforming growth factor beta 1 into rabbit knees. Arthritis Res Ther 2003, 5:R132-139.

88. Hidaka C, Goodrich LR, Chen CT, Warren RF, Crystal RG, Nixon AJ: Acceleration of cartilage repair by genetically modified chondrocytes over expressing bone morphogenetic protein-7. J Orthop Res 2003, 21:573-583.

89. Pathi S, Rutenberg JB, Johnson RL, Vortkamp A: Interaction of Ihh and BMP/Noggin signaling during cartilage differentiation. Dev Biol 1999, 209:239-253.

90. Hannallah D, Peng H, Young B, Usas A, Gearhart B, Huard J: Retroviral delivery of Noggin inhibits the formation of heterotopic ossification induced by BMP-4, demineralized bone matrix, and trauma in an animal model. $J$ Bone Joint Surg Am 2004, 86-A:80-91.

91. Vortkamp A: Interaction of growth factors regulating chondrocyte differentiation in the developing embryo. Osteoarthritis Cartilage 2001, 9(Suppl A):S109-117.

92. Vortkamp A, Lee K, Lanske B, Segre GV, Kronenberg HM, Tabin $\mathrm{CJ}$ : Regulation of rate of cartilage differentiation by Indian hedgehog and PTH-related protein. Science 1996, 273:613622.

93. Minina E, Wenzel HM, Kreschel C, Karp S, Gaffield W, McMahon AP, Vortkamp A: BMP and Ihh/PTHrP signaling interact to coordinate chondrocyte proliferation and differentiation. Development 2001, 128:4523-4534

94. Tavella S, Biticchi R, Schito A, Minina E, Di Martino D, Pagano A Vortkamp A, Horton WA, Cancedda R, Garofalo S: Targeted expression of $\mathrm{SHH}$ affects chondrocyte differentiation, growth plate organization, and Sox9 expression. J Bone Miner Res 2004, 19:1678-1688.

95. Grande DA, Mason J, Light E, Dines D: Stem cells as platforms for delivery of genes to enhance cartilage repair. $J$ Bone Joint Surg Am 2003, 85-A(Suppl 2):111-116.

96. Minina E, Kreschel C, Naski MC, Ornitz DM, Vortkamp A: Interaction of FGF, Ihh/Pthlh, and BMP signaling integrates chondrocyte proliferation and hypertrophic differentiation. Dev Cell 2002, 3:439-449.

97. Harrington EK, Lunsford LE, Svoboda KK: Chondrocyte terminal differentiation, apoptosis, and type $\mathrm{X}$ collagen expression are downregulated by parathyroid hormone. Anat Rec A Discov Mol Cell Evol Biol 2004, 281:1286-1295.

98. Lanske B, Karaplis AC, Lee K, Luz A, Vortkamp A, Pirro A, Karperien M, Defize LH, Ho C, Mulligan RC, et al:: PTH/PTHrP receptor in early development and Indian hedgehog-regulated bone growth. Science 1996, 273:663-666.

99. Lefebvre V, de Crombrugghe B: Toward understanding SOX9 function in chondrocyte differentiation. Matrix Biol 1998, 16: 529-540.

100. Lefebvre V, Behringer RR, de Crombrugghe B: L-Sox5, Sox6 and Sox9 control essential steps of the chondrocyte differentiation pathway. Osteoarthritis Cartilage 2001, 9(Suppl A):S69-75.

101. Tuli R, Tuli S, Nandi S, Huang X, Manner PA, Hozack WJ, Danielson KG, Hall DJ, Tuan RS: Transforming growth factor-betamediated chondrogenesis of human mesenchymal progenitor cells involves $\mathrm{N}$-cadherin and mitogen-activated protein kinase and Wnt signaling cross-talk. J Biol Chem 2003, 278: 41227-41236.

102. Spater D, Hill TP, Gruber M, Hartmann C: Role of canonical Wntsignalling in joint formation. Eur Cell Mater 2006, 12:71-80.

103. Shortkroff S, Yates KE: Alteration of matrix glycosaminoglycans diminishes articular chondrocytes' response to a canonical Wnt signal. Osteoarthritis Cartilage 2007, 15:147-154.

104. Hartmann C, Tabin CJ: Wnt-14 plays a pivotal role in inducing synovial joint formation in the developing appendicular skeleton. Cell 2001, 104:341-351.

105. Nishioka K, Dennis JE, Gao J, Goldberg VM, Caplan Al: Sustained Wnt protein expression in chondral constructs from mesenchymal stem cells. J Cell Physio/ 2005, 203:6-14

106. Evans $\mathrm{CH}$, Georgescu HI: Observations on the senescence of cells derived from articular cartilage. Mech Ageing Dev 1983, 22:179-191.

107. Wendt D, Stroebel S, Jakob M, John GT, Martin I: Uniform tissues engineered by seeding and culturing cells in threedimensional scaffolds under perfusion at defined oxygen tensions. Biorheology 2006, 43:481-488.

108. Martin JA, Buckwalter JA: Telomere erosion and senescence in human articular cartilage chondrocytes. J Gerontol A Biol Sci Med Sci 2001, 56:B172-179.

109. Miura M, Chen XD, Allen MR, Bi Y, Gronthos S, Seo BM, Lakhani $\mathrm{S}$, Flavell RA, Feng $\mathrm{XH}$, Robey $\mathrm{PG}$, et al.: A crucial role of caspase-3 in osteogenic differentiation of bone marrow stromal stem cells. J Clin Invest 2004, 114:1704-1713.

110. Martin JA, Brown TD, Heiner AD, Buckwalter JA: Chondrocyte senescence, joint loading and osteoarthritis. Clin Orthop Relat Res 2004, 427(Suppl):S96-103

111. Campisi J: Senescent cells, tumor suppression, and organismal aging: good citizens, bad neighbors. Cell 2005, 120:513522.

112. Martin JA, Buckwalter JA: The role of chondrocyte senescence in the pathogenesis of osteoarthritis and in limiting cartilage repair. J Bone Joint Surg Am 2003, 85-A(Suppl 2):106-110.

113. Parsch D, Brummendorf TH, Richter W, Fellenberg J: Replicative aging of human articular chondrocytes during ex vivo expansion. Arthritis Rheum 2002, 46:2911-2916.

114. Parsch D, Fellenberg J, Brummendorf TH, Eschlbeck AM, Richter $\mathrm{W}$ : Telomere length and telomerase activity during expansion and differentiation of human mesenchymal stem cells and chondrocytes. J Mol Med 2004, 82:49-55.

115. Martin JA, Klingelhutz AJ, Moussavi-Harami F, Buckwalter JA: Effects of oxidative damage and telomerase activity on 
human articular cartilage chondrocyte senescence. J Gerontol A Biol Sci Med Sci 2004, 59:324-337.

116. Aigner T, Rose J, Martin J, Buckwalter J: Aging theories of primary osteoarthritis: from epidemiology to molecular biology. Rejuvenation Res 2004, 7:134-145.

117. Tuan R: Boning up on telomerase. Nat Biotechnol 2002, 20: $560-561$.

118. Ebert R, Ulmer M, Zeck S, Meissner-Weigl J, Schneider D, Stopper H, Schupp N, Kassem M, Jakob F: Selenium supplementation restores the antioxidative capacity and prevents cell damage in bone marrow stromal cells in vitro. Stem Cells 2006, 24:1226-1235.

119. Hardingham TE, Oldershaw RA, Tew SR: Cartilage, SOX9 and Notch signals in chondrogenesis. J Anat 2006, 209:469-480.

120. Scharstuhl A, Diepens $R$, Lensen J, Vitters E, van Beuningen $H$, van der Kraan $\mathrm{P}$, van den Berg W: Adenoviral overexpression of Smad-7 and Smad-6 differentially regulates TGF-beta-mediated chondrocyte proliferation and proteoglycan synthesis. Osteoarthritis Cartilage 2003, 11:773-782.

121. Ito Y, Bringas P Jr, Mogharei A, Zhao J, Deng C, Chai Y: Receptor-regulated and inhibitory Smads are critical in regulating transforming growth factor beta-mediated Meckel's cartilage development. Dev Dyn 2002, 224:69-78.

122. Evans CH, Ghivizzani SC, Smith P, Shuler FD, Mi Z, Robbins PD: Using gene therapy to protect and restore cartilage. Clin Orthop Relat Res 2000, 379(Suppl):S214-219.

123. Steinert A, Palmer G, Ghivizzani SC, Evans CH: Gene therapy in the treatment of cartilage injury. In Cartilage Injury in the Athlete. Edited by Mirzajan R. New York: Thieme Medical Publishers; 2006:297-308.

124. Li Y, Tew SR, Russell AM, Gonzalez KR, Hardingham TE, Hawkins RE: Transduction of passaged human articular chondrocytes with adenoviral, retroviral, and lentiviral vectors and the effects of enhanced expression of SOX9. Tissue Eng 2004, 10: 575-584.

125. Tew SR, Li Y, Pothacharoen P, Tweats LM, Hawkins RE, Hardingham TE: Retroviral transduction with SOX9 enhances reexpression of the chondrocyte phenotype in passaged osteoarthritic human articular chondrocytes. Osteoarthritis Cartilage 2005, 13:80-89.

126. Cucchiarini M, Thurn T, Weimer A, Kohn D, Terwilliger EF, Madry $\mathrm{H}$ : Restoration of the extracellular matrix in human osteoarthritic articular cartilage by overexpression of the transcription factor SOX9. Arthritis Rheum 2007, 56:158-167.

127. Madry H, Emkey G, Zurakowski D, Trippel SB: Overexpression of human fibroblast growth factor 2 stimulates cell proliferation in an ex vivo model of articular chondrocyte transplantation. J Gene Med 2004, 6:238-245.

128. Gelse K, Jiang QJ, Aigner T, Ritter T, Wagner K, Poschl E, von der Mark K, Schneider H: Fibroblast-mediated delivery of growth factor complementary DNA into mouse joints induces chondrogenesis but avoids the disadvantages of direct viral gene transfer. Arthritis Rheum 2001, 44:1943-1953.

129. Madry H, Kaul G, Cucchiarini M, Stein U, Zurakowski D, Remberger K, Menger MD, Kohn D, Trippel SB: Enhanced repair of articular cartilage defects in vivo by transplanted chondrocytes overexpressing insulin-like growth factor I (IGF-I). Gene Ther 2005, 12:1171-1179.

130. Kaul G, Cucchiarini M, Arntzen D, Zurakowski D, Menger MD, Kohn D, Trippel SB, Madry H: Local stimulation of articular cartilage repair by transplantation of encapsulated chondrocytes overexpressing human fibroblast growth factor 2 (FGF-2) in vivo. J Gene Med 2006, 8:100-111.

131. Cucchiarini M, Madry H, Ma C, Thurn T, Zurakowski D, Menger MD, Kohn D, Trippel SB, Terwilliger EF: Improved tissue repair in articular cartilage defects in vivo by rAAV-mediated overexpression of human fibroblast growth factor 2. Mol Ther 2005, 12:229-238.

132. Haupt JL, Frisbie DD, Mcllwraith CW, Robbins PD, Ghivizzani S, Evans $\mathrm{CH}$, Nixon AJ: Dual transduction of insulin-like growth factor-I and interleukin-1 receptor antagonist protein controls cartilage degradation in an osteoarthritic culture model. $J$ Orthop Res 2005, 23:118-126.

133. Nixon AJ, Brower-Toland BD, Bent SJ, Saxer RA, Wilke MJ, Robbins $\mathrm{PD}$, Evans $\mathrm{CH}$ : Insulinlike growth factor-I gene therapy applications for cartilage repair. Clin Orthop Relat Res 2000, 379(Suppl):S201-213.
134. Palmer GD, Steinert A, Pascher A, Gouze E, Gouze JN, Pilapil C, Betz O, Johnstone B, Evans CH, Ghivizzani SC: Gene-induced chondrogenesis of primary mesenchymal stem cells in vitro. Mol Therapy 2005, 12:219-228.

135. Peretti GM, Xu JW, Bonassar LJ, Kirchhoff CH, Yaremchuk MJ, Randolph MA: Review of injectable cartilage engineering using fibrin gel in mice and swine models. Tissue Eng 2006, 12: 1151-1168.

136. Marcacci M, Berruto $M$, Brocchetta D, Delcogliano A, Ghinelli D, Gobbi A, Kon E, Pederzini L, Rosa D, Sacchetti GL, et al.: Articular cartilage engineering with Hyalograft C: 3-year clinical results. Clin Orthop Relat Res 2005, 435:96-105.

137. Nehrer S, Domayer S, Dorotka R, Schatz K, Bindreiter U, Kotz R: Three-year clinical outcome after chondrocyte transplantation using a hyaluronan matrix for cartilage repair. Eur J Radiol 2006, 57:3-8.

138. Nöth U, Siebenlist S, Rackwitz L, Schreiber B, Steinert A, Barthel $\mathrm{T}$, Eulert J: Matrix-based autologous chondrocyte transplantation for the treatment of large osteochondral defects. In European Musculoskeltal Review 2006. London: Touch Briefings; 2006:62-64

139. Coutts RD, Healey RM, Ostrander R, Sah RL, Goomer R, Amiel D: Matrices for cartilage repair. Clin Orthop Relat Res 2001, 391 (Suppl):S271-279.

140. Temenoff JS, Mikos AG: Review: tissue engineering for regeneration of articular cartilage. Biomaterials 2000, 21:431-440.

141. Mikos AG, Herring SW, Ochareon P, Elisseeff J, Lu HH, Kandel R, Schoen FJ, Toner M, Mooney D, Atala A, et al.: Engineering complex tissues. Tissue Eng 2006, 12:3307-3339.

142. Moutos FT, Freed LE, Guilak F: A biomimetic three-dimensional woven composite scaffold for functional tissue engineering of cartilage. Nat Mater 2007, 6:162-167.

143. Hench LL, Polak JM: Third-generation biomedical materials. Science 2002, 295:1014-1017.

144. Griffith LG, Naughton G: Tissue engineering - current challenges and expanding opportunities. Science 2002, 295:10091014

145. Griffith LG: Emerging design principles in biomaterials and scaffolds for tissue engineering. Ann N Y Acad Sci 2002, 961: 83-95.

146. Yang W, Gomes RR, Brown AJ, Burdett AR, Alicknavitch M, Farach-Carson MC, Carson DD: Chondrogenic differentiation on perlecan domain I, collagen II, and bone morphogenetic protein-2-based matrices. Tissue Eng 2006, 12:2009-2024.

147. Pascher A, Palmer GD, Steinert A, Oligino T, Gouze E, Gouze JN, Betz O, Spector M, Robbins PD, Evans $\mathrm{CH}$, et al.: Gene delivery to cartilage defects using coagulated bone marrow aspirate. Gene Ther 2004, 11:133-141.

148. Samuel RE, Lee CR, Ghivizzani SC, Evans CH, Yannas IV, Olsen BR, Spector M: Delivery of plasmid DNA to articular chondrocytes via novel collagen-glycosaminoglycan matrices. Hum Gene Ther 2002, 13:791-802.

149. Amin AR, Dave M, Attur M, Abramson SB: COX-2, NO, and cartilage damage and repair. Curr Rheumatol Rep 2000, 2:447-453.

150. Kuhn K, D'Lima DD, Hashimoto S, Lotz M: Cell death in cartilage. Osteoarthritis Cartilage 2004, 12:1-16.

151. Lotz M: The role of nitric oxide in articular cartilage damage. Rheum Dis Clin North Am 1999, 25:269-282.

152. Toussaint O, Royer V, Salmon M, Remacle J: Stress-induced premature senescence and tissue ageing. Biochem Pharmacol 2002, 64:1007-1009.

153. Aigner T, Kim HA, Roach HI: Apoptosis in osteoarthritis. Rheum Dis Clin North Am 2004, 30:639-653, xi.

154. Aigner T, Kim HA: Apoptosis and cellular vitality: issues in osteoarthritic cartilage degeneration. Arthritis Rheum 2002, 46:1986-1996.

155. Shakibaei M, Schulze-Tanzil G, de Souza $P$, John T, Rahmanzadeh $M$, Rahmanzadeh R, Merker HJ: Inhibition of mitogen-activated protein kinase kinase induces apoptosis of human chondrocytes. J Biol Chem 2001, 276:13289-13294.

156. Gille J, Ehlers EM, Okroi M, Russlies M, Behrens P: Apoptotic chondrocyte death in cell-matrix biocomposites used in autologous chondrocyte transplantation. Ann Anat 2002, 184:325332.

157. D'Lima DD, Hashimoto S, Chen PC, Lotz MK, Colwell CW Jr: Cartilage injury induces chondrocyte apoptosis. J Bone Joint Surg Am 2001, 83-A(Suppl 2):19-21. 
158. D'Lima DD, Kuhn K, Lotz MK: Detection of apoptosis in cartilage in situ and in isolated chondrocytes. Methods Mol Med 2004, 100:275-290.

159. Yao Q, Wang S, Gambotto A, Glorioso JC, Evans CH, Robbins PD, Ghivizzani SC, Oligino TJ: Intra-articular adenoviral-mediated gene transfer of trail induces apoptosis of arthritic rabbit synovium. Gene Ther 2003, 10:1055-1060.

160. Hock JM, Krishnan V, Onyia JE, Bidwell JP, Milas J, Stanislaus D: Osteoblast apoptosis and bone turnover. J Bone Miner Res 2001, 16:975-984.

161. Surendran S, Kim SH, Jee BK, Ahn SH, Gopinathan P, Han CW: Anti-apoptotic $\mathrm{Bcl}-2$ gene transfection of human articular chondrocytes protects against nitric oxide-induced apoptosis. $J$ Bone Joint Surg Br 2006, 88-B:1660-1665.

162. Costouros JG, Kim HT: Preventing chondrocyte programmed cell death caused by iatrogenic injury. Knee 2007, 14:107-111.

163. Hwang SG, Ryu JH, Kim IC, Jho EH, Jung HC, Kim K, Kim SJ, Chun JS: Wnt-7a causes loss of differentiated phenotype and inhibits apoptosis of articular chondrocytes via different mechanisms. J Biol Chem 2004, 279:26597-26604.

164. Holler N, Kataoka T, Bodmer JL, Romero P, Romero J, Deperthes D, Engel J, Tschopp J, Schneider P: Development of improved soluble inhibitors of FasL and CD40L based on oligomerized receptors. J Immunol Methods 2000, 237:159-173.

165. Holler N, Zaru R, Micheau O, Thome M, Attinger A, Valitutti S, Bodmer JL, Schneider P, Seed B, Tschopp J: Fas triggers an alternative, caspase-8-independent cell death pathway using the kinase RIP as effector molecule. Nat Immuno/ 2000, 1:489-495.

166. Majno G, Joris I: Apoptosis, oncosis, and necrosis. An overview of cell death. Am J Pathol 1995, 146:3-15.

167. Aigner T, Haag J, Martin J, Buckwalter J: Osteoarthritis: aging of matrix and cells - going for a remedy. Curr Drug Targets 2007, 8:325-331

168. D'Lima DD, Hashimoto S, Chen PC, Colwell CW Jr, Lotz MK: Impact of mechanical trauma on matrix and cells. Clin Orthop Relat Res 2001, 391(Suppl):S90-99.

169. D'Lima DD, Hashimoto S, Chen PC, Colwell CW Jr, Lotz MK: Human chondrocyte apoptosis in response to mechanical injury. Osteoarthritis Cartilage 2001, 9:712-719.

170. Chen AC, Klisch SM, Bae WC, Temple MM, McGowan KB, Gratz KR, Schumacher BL, Sah RL: Mechanical characterization of native and tissue-engineered cartilage. Methods $\mathrm{Mol} \mathrm{Med}$ 2004, 101:157-190.

171. Gratz KR, Wong VW, Chen AC, Fortier LA, Nixon AJ, Sah RL: Biomechanical assessment of tissue retrieved after in vivo cartilage defect repair: tensile modulus of repair tissue and integration with host cartilage. J Biomech 2006, 39:138-146.

172. Loening AM, James IE, Levenston ME, Badger AM, Frank EH, Kurz $\mathrm{B}$, Nuttall ME, Hung HH, Blake SM, Grodzinsky AJ, et al:: Injurious mechanical compression of bovine articular cartilage induces chondrocyte apoptosis. Arch Biochem Biophys 2000, 381:205-212

173. Clements KM, Hollander AP, Sharif M, Adams MA: Cyclic loading can denature type II collagen in articular cartilage. Connect Tissue Res 2004, 45:174-180.

174. Hunter CJ, Imler SM, Malaviya P, Nerem RM, Levenston ME: Mechanical compression alters gene expression and extracellular matrix synthesis by chondrocytes cultured in collagen I gels. Biomaterials 2002, 23:1249-1259.

175. Waldman SD, Spiteri CG, Grynpas MD, Pilliar RM, Kandel RA: Long-term intermittent compressive stimulation improves the composition and mechanical properties of tissue-engineered cartilage. Tissue Eng 2004, 10:1323-1331.

176. Lee JH, Kisiday J, Grodzinsky AJ: Tissue-engineered versus native cartilage: linkage between cellular mechano-transduction and biomechanical properties. Novartis Found Symp 2003, 249:52-64; discussion 64-59, 170-174, 239-141.

177. Kobayashi K, Mishima H, Hashimoto S, Goomer RS, Harwood FL, Lotz M, Moriya H, Amiel D: Chondrocyte apoptosis and regional differential expression of nitric oxide in the medial meniscus following partial meniscectomy. J Orthop Res 2001, 19:802808.

178. Lotz M: Cytokines in cartilage injury and repair. Clin Orthop Relat Res 2001, 391(Suppl):S108-115.

179. Arend WP, Evans $\mathrm{CH}$ : Interleukin-1 receptor antagonist. In The Cytokine Handbook. 4th edition Edited by Thomson AW, Lotze MT. London: Academic Press; 2003:669-708.
180. Fernandes JC, Martel-Pelletier J, Pelletier JP: The role of cytokines in osteoarthritis pathophysiology. Biorheology 2002 39:237-246.

181. Majumdar MK, Wang E, Morris EA: BMP-2 and BMP-9 promotes chondrogenic differentiation of human multipotential mesenchymal cells and overcomes the inhibitory effect of IL-1. J Cell Physiol 2001, 189:275-284.

182. Robbins PD, Evans $\mathrm{CH}$, Chernajovsky $\mathrm{Y}$ : Gene therapy for arthritis. Gene Ther 2003, 10:902-911.

183. Evans CH, Gouze JN, Gouze E, Robbins PD, Ghivizzani SC: Osteoarthritis gene therapy. Gene Ther 2004, 11:379-389.

184. Fleischmann RM, Schechtman J, Bennett R, Handel ML, Burmester GR, Tesser J, Modafferi D, Poulakos J, Sun G: Anakinra, a recombinant human interleukin-1 receptor antagonist ( $r$-metHulL-1ra), in patients with rheumatoid arthritis: A large, international, multicenter, placebo-controlled trial. Arthritis Rheum 2003, 48:927-934.

185. Ghivizzani SC, Lechman ER, Kang R, Tio C, Kolls J, Evans CH, Robbins PD: Direct adenovirus-mediated gene transfer of interleukin 1 and tumor necrosis factor alpha soluble receptors to rabbit knees with experimental arthritis has local and distal anti-arthritic effects. Proc Natl Acad Sci USA 1998, 95: 4613-4618.

186. Nixon AJ, Haupt JL, Frisbie DD, Morisset SS, Mcllwraith CW, Robbins PD, Evans $\mathrm{CH}$, Ghivizzani S: Gene-mediated restoration of cartilage matrix by combination insulin-like growth factor-I/interleukin-1 receptor antagonist therapy. Gene Ther 2005, 12:177-186.

187. Pelletier JP, Caron JP, Evans C, Robbins PD, Georgescu HI, Jovanovic D, Fernandes JC, Martel-Pelletier J: In vivo suppression of early experimental osteoarthritis by interleukin- 1 receptor antagonist using gene therapy. Arthritis Rheum 1997, 40:1012-1019.

188. Makarov SS, Olsen JC, Johnston WN, Anderle SK, Brown RR Baldwin AS Jr, Haskill JS, Schwab JH: Suppression of experimental arthritis by gene transfer of interleukin 1 receptor antagonist cDNA. Proc Natl Acad Sci USA 1996, 93:402-406.

189. Gouze JN, Gouze E, Palmer GD, Liew VS, Pascher A, Betz OB Thornhill TS, Evans CH, Grodzinsky AJ, Ghivizzani SC: A comparative study of the inhibitory effects of interleukin-1 receptor antagonist following administration as a recombinant protein or by gene transfer. Arthritis Res Ther 2003, 5:R301-309.

190. Gouze E, Pawliuk R, Pilapil C, Gouze JN, Fleet C, Palmer GD Evans $\mathrm{CH}$, Leboulch $\mathrm{P}$, Ghivizzani SC: In vivo gene delivery to synovium by lentiviral vectors. Mol Ther 2002, 5:397-404.

191. Gouze E, Pawliuk R, Gouze JN, Pilapil C, Fleet C, Palmer GD Evans $\mathrm{CH}$, Leboulch $\mathrm{P}$, Ghivizzani SC: Lentiviral-mediated gene delivery to synovium: potent intra-articular expression with amplification by inflammation. Mol Ther 2003, 7:460-466.

192. Baragi VM, Renkiewicz RR, Jordan H, Bonadio J, Hartman JW, Roessler BJ: Transplantation of transduced chondrocytes protects articular cartilage from interleukin 1-induced extracellular matrix degradation. J Clin Invest 1995, 96:2454-2460.

193. Bakker AC, Joosten LA, Arntz OJ, Helsen MM, Bendele AM, van de Loo FA, van den Berg WB: Prevention of murine collageninduced arthritis in the knee and ipsilateral paw by local expression of human interleukin-1 receptor antagonist protein in the knee. Arthritis Rheum 1997, 40:893-900.

194. Evans CH, Robbins PD, Ghivizzani SC, Herndon JH, Kang R, Bahnson AB, Barranger JA, Elders EM, Gay S, Tomaino MM, et al.: Clinical trial to assess the safety, feasibility, and efficacy of transferring a potentially anti-arthritic cytokine gene to human joints with rheumatoid arthritis. Hum Gene Ther 1996, 7:12611280.

195. Evans CH, Robbins PD, Ghivizzani SC, Wasko MC, Tomaino MM, Kang R, Muzzonigro TA, Vogt M, Elder EM, Whiteside TL, et al.: Gene transfer to human joints: progress toward a gene therapy of arthritis. Proc Natl Acad Sci USA 2005, 102:86988703.

196. Evans CH, Gouze E, Gouze JN, Robbins PD, Ghivizzani SC: Gene therapeutic approaches-transfer in vivo. Adv Drug Deliv Rev 2006, 58:243-258.

197. Dharmavaram RM, Liu G, Tuan RS, Stokes DG, Jimenez SA Stable transfection of human fetal chondrocytes with a type II procollagen minigene: expression of the mutant protein and alterations in the structure of the extracellular matrix in vitro. Arthritis Rheum 1999, 42:1433-1442. 
198. Obradovic B, Martin I, Padera RF, Treppo S, Freed LE, VunjakNovakovic G: Integration of engineered cartilage. J Orthop Res 2001, 19:1089-1097.

199. Hunter CJ, Levenston ME: Maturation and integration of tissueengineered cartilages within an in vitro defect repair model. Tissue Eng 2004, 10:736-746.

200. Kreklau B, Sittinger M, Mensing MB, Voigt C, Berger G, Burmester GR, Rahmanzadeh R, Gross U: Tissue engineering of biphasic joint cartilage transplants. Biomaterials 1999, 20: 1743-1749.

201. Hutmacher DW, Ng KW, Kaps C, Sittinger M, Klaring S: Elastic cartilage engineering using novel scaffold architectures in combination with a biomimetic cell carrier. Biomaterials 2003, 24:4445-4458.

202. Tuli R, Nandi S, Li WJ, Tuli S, Huang X, Manner PA, Laquerriere P, Noth $U$, Hall DJ, Tuan RS: Human mesenchymal progenitor cell-based tissue engineering of a single-unit osteochondral construct. Tissue Eng 2004, 10:1169-1179.

203. Shao X, Goh JC, Hutmacher DW, Lee EH, Zigang G: Repair of large articular osteochondral defects using hybrid scaffolds and bone marrow-derived mesenchymal stem cells in a rabbit model. Tissue Eng 2006, 12:1539-1551.

204. Waldman SD, Grynpas MD, Pilliar RM, Kandel RA: The use of specific chondrocyte populations to modulate the properties of tissue-engineered cartilage. J Orthop Res 2003, 21:132138.

205. Klein TJ, Schumacher BL, Schmidt TA, Li KW, Voegtline MS, Masuda K, Thonar EJ, Sah RL: Tissue engineering of stratified articular cartilage from chondrocyte subpopulations. Osteoarthritis Cartilage 2003, 11:595-602. 